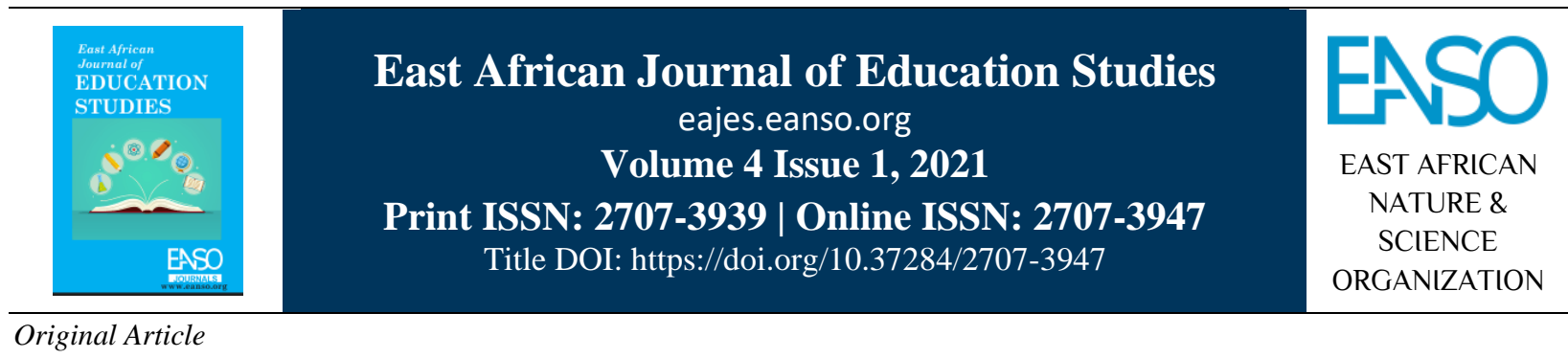

\title{
Effect of Teacher Participation on Decision-making Processes on Performance in Secondary Schools in Mombasa County, Kenya.
}

\author{
Dr. Jerono Kiprop-Marakis, $P h D^{* 1}$ \\ ${ }^{1}$ University of Eldoret; P. O. Box 980-30100 Eldoret, Kenya. \\ * Author for Correspondence Email: marakis.p72@gmail.com.
}

Article DOI: https://doi.org/10.37284/eajes.4.1.437

\section{Date Published: ABSTRACT}

15 October 2021 Decision-making is one of the tools that the school management uses to run schools. Teachers play an important role in the performance of schools. This

Keywords: paper looked at the effects of teacher participation in decision-making processes on performance. The study was conducted in public secondary

Decision-Making, schools in Mombasa County, Kenya. The study used the mixed methods Teacher Participation, approach where qualitative and quantitative research methods were used. The Performance. study targeted 474 teachers in 24 public schools in the County. These 10 schools were selected through purposive sampling and 110 teachers were selected through the simple random sampling technique. Data were obtained through questionnaires. Descriptive statistics were used to analyse data using mean, frequencies, standard deviation and percentages and the findings were presented using tables. The study found that teachers were partially involved in the decision-making process in the school since they participated mostly in one area more than the others. The findings from the study draw the conclusion that teachers in Mombasa County do not participate fully in the decisionmaking process in their schools. The study recommends that teachers be more empowered and engaged in decision-making processes in all aspects of the school system.

\section{APA CITATION}

Marakis, J. K. (2021). Effect of Teacher Participation on Decision-making Processes on Performance in Secondary Schools in Mombasa County, Kenya. East African Journal of Education Studies, 4(1), 29-36. https://doi.org/10.37284/eajes.4.1.437.

\section{CHICAGO CITATION}

Marakis, Jerono Kiprop. 2021. "Effect of Teacher Participation on Decision-making Processes on Performance in Secondary Schools in Mombasa County, Kenya". East African Journal of Education Studies 4 (1), 29-36. https://doi.org/10.37284/eajes.4.1.437. 


\section{HARVARD CITATION}

Marakis, J. K. (2021) "Effect of Teacher Participation on Decision-making Processes on Performance in Secondary Schools in Mombasa County, Kenya”, East African Journal of Education Studies, 4(1), pp. 29-36. doi: 10.37284/eajes.4.1.437.

\section{IEEE CITATION}

J. K. Marakis, "Effect of Teacher Participation on Decision-making Processes on Performance in Secondary Schools in Mombasa County, Kenya", EAJES, vol.4, no. 1, pp. 29-36, Oct. 2021.

\section{MLA CITATION}

Marakis, Jerono Kiprop. "Effect of Teacher Participation on Decision-making Processes on Performance in Secondary Schools in Mombasa County, Kenya". East African Journal of Education Studies, Vol. 3, no. 1, Oct. 2021, pp. 29-36, doi:10.37284/eajes.4.1.437.

\section{INTRODUCTION}

Decision-making in schools is required as a management tool in the running of the institutions. Okumbe (2008) defines decision-making as the process of identifying and choosing between alternatives based on values and preferences. The traditional management approaches are autocratic and bureaucratic in nature while the modern practices are participative, consultative, team and task-oriented. Bell and Bush (2002) recommend processes of decision-making that include listening and responding rather than telling and prescribing. This is the participative (participatory) decisionmaking (PDM). PDM is the involvement of stakeholders at all levels of decision-making from the analysis of problems, development of strategies to the implementation of solutions (Steinheider, Bayerl \& Wuestewald, 2012). PDM also involves the management treating the ideas and suggestions of subordinates with consideration and respect. In essence, all stakeholders in education and particularly in a school system ought to be involved in the decision-making process for the attainment of organisational goals (Pashiardis, 2014). The most important group among the stakeholders is the teachers (Kiprop-Marakis, Kipkoech \& Ferej, 2019). A study by Khoza (2004) indicated that teachers had an important influence on the schools' performance. This is because the teacher is ultimately responsible for translating policy into actions and principles based on practice particularly because they interact more with the students. Allowing teachers to help in making decisions may increase their productivity levels due to increased self-esteem. As professionals and specialists in different subject areas, teachers are better suited to make decisions particularly those that affect the performance of the students. However, Khoza (2004) warns that workers feel reluctant to participate in decisions when they lack expertise but are readily available for decisions in which they have a personal stake in the outcome.

In Kenya, decisions about the running of schools are made at the national, county level or in Board of Management meetings where teachers are not involved, yet, their performance is measured by looking at student outcomes. The Basic Education Act No. 14 (RoK, 2013) established structures of governance and management of basic education whereby it encourages cooperation and collaboration among all stakeholders. Moreover, involving subordinates in decision-making may improve the quality of the decision and the effectiveness of the organisation leading to the achievement of the organisational goals. Although the Basic Education Act 2013 encourages a culture of dialogue and participatory democratic governance in all institutions, its implementation is yet to be seen in most institutions in Kenya as teachers have remained to be mostly the recipients of decisions and instructions.

The decision-making process in most schools in Kenya can be a hindrance to the achievement of goals in most institutions. The performance of students in national examinations is a critical factor for any institution. Poor performance indicates the need for stakeholders to investigate the reasons for it. Many studies have been conducted on the reasons for poor performance in national exams in public secondary schools in Kenya. Odongo (2014) concluded that democratic leadership style affected students and general school performance positively and motivated teachers to work with principals towards the achievement of school objectives. However, this study did not indicate how teachers should work with the principals. A school in which teachers are motivated is likely to have fewer 
disciplinary problems among teachers and consequently among students (Mugambi, 2018). Teachers in such a school are likely to be more committed to the school's mission. Public secondary schools in Mombasa County have not been performing well in most domains of learning. As a result, this study sought to establish whether teachers' involvement in decision-making processes in secondary schools in Mombasa County had an effect on the performance of students.

\section{Statement of the Problem}

Secondary schools in Kenya use the hierarchical structure that places headteachers at the apex of the pyramid of the staff. In this arrangement, school heads are poised to use their superior knowledge and experience to direct and control the working of the entire school (Mualuko et al., 2009). The Basic Education Act No. 14 of 2013 gives powers to the headteacher in decision-making, policy formulation and implementation with the assistance of the Board of Management. This kind of structure leaves out the inputs of the most important stakeholders in the school, the teachers. Teachers expect to have a stake in the running of schools (Okumbe, 2008). But, how often are these teachers involved in decisionmaking processes particularly on issues that affect learner outcomes? The study sought to examine the effect of teacher participation in the decisionmaking process on the performance of public secondary schools in Mombasa County, Kenya.

\section{LITERATURE REVIEW}

Decision-making is the process whereby an individual, group or organisation reaches conclusions about what future actions to pursue given a set of objectives and limits on available resources (Paul \& Russo, 2014). A problem precedes any decision and there must be a number of alternatives and courses of action from which an optimum course is selected (Okumbe, 2008). Decision-making is indeed a daily activity for any organisation. The staff in any organisation need to take part in the decision-making process before the implementation of a project or programme (Olorunsola \& Abiodun, 2011). Khoza (2004) observed that headteachers had tendencies of dominating every activity in the school and they usually applied spying styles on their teachers since they did not trust them. However, teachers are often displeased with this kind of leadership because they feel left out and their inputs are not valued. This sometimes creates a rift between the headteacher and the teachers and may lead to a loss of focus on the schools' objectives (Pashiardis, 2014). Consequently, there is the low performance of the teachers which eventually affects the schools' performance. A leader may consult and solicits opinions from the group before making decisions yet does not feel obliged to accept the group's thinking.

Okumbe (2008) believed that a leader makes their subordinates aware of how important their jobs are for the organisation and how necessary it is for them to perform those jobs as best as they can for the organisation to attain its goals. The staff is therefore invited to share in the decision-making process of the organisation by participating in activities such as setting goals, determining work schedules, and making suggestions. It has been proven that teachers have an important influence on students' academic achievement (Kimani, Kara \& Njagi, 2013). In their study, Steinheideret al. (2012) concluded that the most important factor influencing student learning is the teacher. Teachers stand in the interface of the transmission of knowledge, values and skills in the learning process (Mungunda, 2013). If the teacher is ineffective, students under the teacher's tutelage will achieve inadequate progress academically.

School-based decision-making devolves the main decision-making authority to teachers. The goal of school-based decision-making is to "empower school staff by providing authority, flexibility, and resources to solve the educational problems particular to their schools" (Steinheider et al., 2012). This model aims to make better use of teachers' knowledge of what the school needs at the classroom level. When the principal allows teachers to participate in certain aspects of the management of the school, she/he gives an opportunity to teachers to experience responsibility (Olorunsola \& Abiodun, 2011). By so doing, the principal does not relinquish his/her authority, but his/her authority is enhanced. Odongo (2014) agrees with the above assumptions on the strength that teachers who are encouraged to participate democratically in the decision-making process are reported to be more positive and committed to the school as an 
organisation. As a result of this, teachers will have wider and greater ownership of the school, its vision and priorities. School heads, like any other persons, may not know everything hence, the need for consultations and teamwork in decision-making.

Participating fully in the decision-making process can also motivate teachers to perform better and can lead to greater efficiency and effectiveness in teaching (Jematia \& Jeruto, 2012). Their study found that teachers who were given an opportunity to participate in a collective decision-making process suggested an increase in their commitment to implementing the peace-making initiatives. In contrast, decisions about at least one peace-making initiative in the school that did not involve staff sufficiently in the decision-making process were poorly implemented. These findings suggest that it may be important to involve teachers in the decision-making process, especially when the decisions made will require significant time and energy for teachers to implement. More importantly, it may be wise to take time to invite teachers at the beginning of the process when the problem is being discussed and allow them to work through diagnosing the cause of the concern and find solutions to the problem collaboratively. This was seen as a catalyst to motivate teachers to support each other in implementing the decisions (Pashiardis, 2014).

According to Rivkin, Hanusheck and Kain (2005), there has never been consensus on the specific teacher factors that influence students' academic achievement. Researchers have examined the influence of teacher characteristics such as gender, educational qualifications and teaching experience on students' academic achievement with varied findings. Omobude (2012) study on the influence of teachers' participation in decision-making on their job performance in public and private secondary schools in Oredo local government area of Edo State, Nigeria, revealed that those who participated performed better. However, this study was only interested in the relationship between participation and performance on the basis of sex, experience and qualification. Yala and Wanjohi (2011), and Adeyemi (2010), found that teachers' experience and educational qualifications were the prime predictors of students' academic achievement. However, Rivkin et al. (2005) found that teachers' teaching experience and educational qualifications were not significantly related to students' achievement.

In Kenya, its only principals who have a direct dealing with the Board of Management which is a representative of the Ministry of Education. The principal's function is to pass information to teachers for implementation. Mualuko et al. (2009) show that teachers expressed the need to be involved in decision-making more than they were actually involved. Pashiardis (2014) observed that headteachers dominated staff meetings and exhibited domineering tendencies, thereby hampering the participation of the teaching staff in the schools' decisions that affect performance. Denying teachers to participate in the decisionmaking process denies them that personal touch and ego that makes them feel proud of their contribution. This act demoralises teachers and may lead to the development of a negative attitude towards the school. The net effect is that teachers feel greatly marginalised and, consequently, disinterested in the school's mission. According to Odongo (2014), the talents, skills and abilities of almost all the employees in most organisations in Kenya lie fallow because of inadequate involvement of staff members in task performance and decisionmaking. Consequently, productivity and employee satisfaction remain extremely low. Schools are no exception. A principal who does not provide an environment that motivates teachers to participate in the decision-making activity risks having a workforce that is non-committed to the achievement of the organisations' goals. This trend may consequently lead to poor performance. This study, therefore, sought to find out the extent of teacher participation in decision-making and how it affects the performance of schools.

\section{MATERIALS AND METHODS}

This study adopted both the quantitative research paradigm (Cohen, Manion \& Morrison, 2007). Questionnaires were used as instruments for data collection. The study was undertaken in Mombasa County in the Coast region of Kenya. The target population for this study consisted of all the teachers in public secondary schools in Mombasa County with the exception of newly established schools that had not been fully registered. Specifically, a total of 
474 teachers in 24 public secondary schools in Mombasa County were used. A sample of 10 schools in the County was selected through purposive sampling. In addition, 110 secondary school teachers were selected using simple random sampling. The data collected was analysed using qualitative and quantitative methods. Quantitative data was analysed using frequencies, percentages and correlations, while qualitative data was analysed using content analysis. The findings in this study were presented using tables.

\section{RESULTS AND DISCUSSION}

\section{The Extent of Teachers' Participation in Decision-making}

Teachers were required to state the stage at which they participated most in the decision-making process in their schools. Results were tabulated in Table 1.

Table 1: Stage of Teacher Participation in the Decision-Making Process

\begin{tabular}{ll}
\hline Stage of involvement & Percent \\
\hline Analysis of the problem & 19.0 \\
Formulation and development & 59.0 \\
Implementation & 22.0 \\
Total & $\mathbf{1 0 0 . 0}$ \\
\hline
\end{tabular}

The analysis in Table 1 shows responses for teachers on the stage of their participation in decision-making processes in the school. Findings show that $19.0 \%$ indicated that they participated in the analysis of the problem stage, $59.0 \%$ participated at the formulation and development stage, while $22.0 \%$ participated at the implementation stage. The results indicate that majority of teachers got involved at the formulation and development stages which are the core phases in the decision-making process. The implication from this result was that the extent of teachers participating in decision-making was limited. The decision-making process is a step-by-step analysis of the problem with a view to arriving at a solution. According to Steinheider et al. (2012), the process includes the definition of the problem, its analysis, developing alternative solutions, deciding on the best alternative and converting decisions into effective actions. From the finding, teachers' participation was below average, especially in the analysis of the problem and implementation of solutions. It is clear that the teachers participate in one area of decision-making more than the other areas, yet all the areas are critical for the success of the school programs. This may not contribute much to the good performance of the learners since these teachers are not made to feel valuable nor are, they empowered to implement their decisions. This is against the fundamental principle that those individuals, who are affected by the decision, possess expertise regarding the decision. These individuals are also responsible for implementing the decision, and therefore should be involved more in the decision-making process for successful implementation of the decision (Mugambi, 2018).

From the findings, it is clear that teachers want to participate more in the schools' decisions as they work towards the achievement of the set goals. In support of this assertion, Odongo (2014) intimated that subordinates find it hard to execute decisions made without their knowledge since they do not have a clear picture of what they are implementing. Mungunda (2013) concur and says that effective implementation of any decision depends largely on the acceptance and support by other people. Their feelings regarding the decisions may account for the success or failure of the decision. Where teachers are allowed to make a contribution towards decision-making, the headteachers will find it easy to implement changes since the staff are able to own their decisions. The findings in this study concur with (Jematia \& Jeruto, 2012), which suggested that teachers need to be invited in at the beginning of the process when the problem is being discussed and allowed to work through diagnosing the cause of the concern and find solutions to the problem collaboratively. This seems to motivate the teachers to support each other in implementing the decisions. 


\section{Effect of Teacher Participation on Decision- making on Performance}

Teachers were requested to give their opinions on whether teachers' participation in the decision- making process in the school had an impact on school administration, school activities, academic performance, and school discipline and student dropout rate. The response was captioned as either Yes or No. results are represented in Table 2.

Table 2: Effect of Teacher Participation on Decision-making on Performance

\begin{tabular}{lll}
\hline Effects & Response & Percent \\
\hline Administration of the school & Yes & 49.0 \\
& No & 51.0 \\
& Total & 100.0 \\
\hline School activities & Yes & 26.0 \\
& No & 74.0 \\
& Total & 100.0 \\
\hline Academic performance & Yes & 63.0 \\
& No & 37.0 \\
School discipline & Total & 100.0 \\
& Yes & 78.0 \\
& No & 22.0 \\
Dropout rates & Total & 100.0 \\
& Yes & 36.0 \\
& No & 64.0 \\
\hline
\end{tabular}

The analysis in Table 2 shows that almost a half $(49.0 \%)$ of teachers agreed that their participation in decision-making had an impact on the administration of the school, while $51.0 \%$ disagreed, $26.0 \%$ of teachers agreed participation had an impact on other school activities, whereas $74.0 \%$ did not agree. More than half of the teachers $(63.0 \%)$ agreed their participation in decisionmaking had an impact on the academic performance of the school, while $3.0 \%$ were in disagreement. Most teachers (78.0\%) said their participation had an impact on students' discipline. Impact on student dropout rates had $36.0 \%$ of teachers agreeing while $64.0 \%$ disagreed. From the results, it is clear that teachers agreed that decision-making had an impact on all areas of the school. However, most respondents rated school discipline as one of the areas that are greatly affected by the decisions that were made by teachers. The implication from these findings was that for a school to perform well academically, discipline must be upheld. Learners' behaviour in a school has a direct bearing on their performance. Teachers also agreed that the academic performance of the school was greatly affected by the decisions they make as teachers. Most educators define performance in terms of standardised test scores and exam results. However, Maicibi (2003) says that performance is inclusive of the students' ability to socially apply what is learnt, student attendance, percentage of dropouts and the number of discipline cases in a school among other factors.

Effective performance in a school cannot be realised without a proper leadership style. Most schools may have all the required instructional materials and financial resources but they are not performing well. The reason for this non-performance can be attributed to the failure of the teachers to provide guidance to the students. This can happen in a situation where teachers have not been given the opportunity to participate in the decision-making process of the school. Performance can only be achieved when there is proper interaction of features of the school organisation such as school administration, teachers and instructional resources. Teachers, therefore, see themselves as the key ingredient to the academic achievement of students through their participation in the decisions that affect them. The average agreement on the impact of their participation in school administration could be explained by the fact that most teachers were not 
involved in administrative decisions hence could not contribute much in this area. Nevertheless, they were in agreement that the decision-making process had an impact in this area also.

\section{CONCLUSION AND RECOMMENDATIONS}

The findings from this study show that teachers in Mombasa County did not participate fully in the decision-making activity of the school. The majority participated in only one stage of the decision-making process. Their involvement was mostly on a group basis. The decision-making process is a step-by-step analysis of the problem with a view to arriving at a solution. The involvement of teachers in the decision-making process is often seen to be closely related to the teachers' commitment, motivation and job satisfaction. Therefore, the study concluded that teachers were demotivated and demoralised because they were not involved in most decisions in the school. Consequently, their performance in their duties was lowered leading to poor performance of the school. Further, the findings from the study show that teacher participation in decision-making had an effect in all areas of the school system. The areas that teachers' participation had the greatest effect were on student discipline and academic performance. Teachers' participation in decisions about school activities and dropout rates were not seriously affected. The study recommends teacher empowerment and engagement in decision-making processes in all aspects of the school system as a motivation for improved performance of schools

\section{REFERENCES}

Adeyemi, B. (2010). Teacher-related factors as correlates of pupils' achievement in Social Studies in Southwestern Nigeria. Electronic Journal of Research in Educational Psychology, 8(1).

Bell, L., \& Bush, T. (2002). The Policy Context.

Cohen, L., Manion, L., \& Morrison, K. (2002). Research methods in education. Routledge.

Jematia, C. K. \& Jeruto, S. K. (2012). An investigation into teacher participation in decision-making in public secondary schools in
Kenya: a case of Baringo district. Elixir Edu. Tech., 53, $11824-11828$.

Khoza, S. F. (2004). Teacher Participation in Sitebased Management in Schools: A case study (Doctoral dissertation).

Kimani, G. N., Kara, A. M., \& Njagi, L. W. (2013). Teacher Factors Influencing Students'academic Achievement in Secondary Schools in Nyandarua County, Kenya.

Kiprop-Marakis, J., Kipkoech, L. \& Ferej, A.K. (2019). Effect of ethnic conflicts on teachers instructional performance in public secondary schools in lower areas of Baringo County, Kenya. European Journal of Education Studies, 6(7), 309 - 321. Doi:10.5281/zenodo.3522876.

Maicibi, N. A. (2003). Pertinent issues in employees 'management: human resource and educational management. Kampala. Net Media Monitor Publishers.

Mualuko, N. J., Mukasa, S. A., \& Judy, A. S. (2009). Improving decision-making in schools through teacher participation. Educational Research and Reviews, 4(8), 391-397.

Migwi, C. M. (2018). Influence of teacher participation in decision-making on job motivation in public secondary schools in Nyeri, Nairobi and Kajiado Counties, Kenya. Kenyatta University.

Mungunda, C. (2003). An Investigation into School Principals' Experience and Perceptions of Participative Management. Rhodes University.

Odongo, F. O. (2014). The relationship between teachers' participation in decision-making and their job satisfaction in public secondary schools in Gem Sub-County, Siaya County, Kenya.

Okumbe, J. A. O. (1998). Educational Management: Theory and Practice. African Books Collective Ltd.

Olorunsola, E. O. \& Abiodun, O.O. (2011) Teachers' participation in decision-making process in secondary schools in Ekiti State, Nigeria. International Journal of Education Administration and Policy Studies, 3(6), 78 - 84.

35 This work is licensed under a Creative Commons Attribution 4.0 International License 
Omobude, M., \& Igbudu, U. (2012). Influence of teachers participation in decision-making on their job performance in public and private secondary schools in Oredo local government area of Edo State, Nigeria. European Journal of Business and Social Sciences, 1(5), 12-22.

Pashiardis, P. (2014). Teachers Participation in Decision-Making. International Journal of Educational Management. 8(5), pp. 1417.

Paul J.H. \& Russo E.J. (2014). Decision-making.

R.o.K. (2013). The basic education Act No. 4 of 2013. Nairobi: Government Printing Press.

Rivkin, S. G., Hanushek, E. A., \& Kain, J. F. (2005). Teachers, schools, and academic achievement. Econometrica, 73(2), 417-458.

Steinheider, B., Bayerl, P. S., \& Wuestewald, T. (2012). The effects of participative management on teacher commitment, productivity, and community satisfaction in a police agency. Paper presented at the annual meeting of the International Communication Association, Dresden International Congress Centre, Dresden, Germany.

Yala, P. O., \& Wanjohi, W. C. (2011). Performance determinants of KCSE in mathematics in secondary schools in Nyamira Division, Kenya. Asian Social Science, 7(20), 107-112. 